\title{
KAJIAN EFEKTIVITAS KALSIUM UNTUK PENGEMBANGAN TEKNOLOGI INTENSIF PADA BUDIDAYA LOBSTER AIR TAWAR (Cherax quadricarinatus)
}

\author{
Lies Emmawati Hadie"), Wartono Hadie"), dan Irin Iriana Kusmini"*) \\ *) Pusat Riset Perikanan Budidaya \\ Jl. Ragunan 20, Pasar Minggu, Jakarta Selatan 12540 \\ E-mail:ema_hadi@yahoo.com \\ *) Balai Riset Perikanan Budidaya Air Tawar \\ Jl. Raya Sempur No.1, Bogor 16154
}

(Naskah diterima: 8 April 2010; Disetujui publikasi: 12 Agustus 2010)

\begin{abstract}
ABSTRAK
Dalam proses pertumbuhan lobster dibutuhkan mineral kalsium (Ca) yang dapat dicukupi dari makanan dan lingkungan. Pada fase pengerasan kulit diperlukan kalsium yang cukup tinggi. Kebutuhan akan kalsium tidak dapat dipenuhi dari dalam tubuhnya yang tersimpan di dalam hemolimf. Oleh karena itu, diperlukan kajian tentang efektivitas mineral kalsium di dalam air pada budidaya lobster. Penelitian dilakukan secara in door pada bak semen yang dilengkapi dengan sistem resirkulasi. Rancangan penelitian dilakukan dengan menggunakan Rancangan Acak Lengkap dengan 4 perlakuan konsentrasi penambahan calcium hydroxyde ke dalam media yaitu $0 \mathrm{mg} / \mathrm{L}, 5 \mathrm{mg} / \mathrm{L}$, $10 \mathrm{mg} / \mathrm{L}$, dan $15 \mathrm{mg} / \mathrm{L}$. Masing-masing perlakuan mendapat 3 ulangan. Hasil penelitian menunjukkan bahwa efek pemberian kalsium $\left(\mathrm{CaOH}_{2}\right)$ pada lobster tawar terlihat secara signifikan memberikan efek yang positif dan jauh lebih baik dibandingkan dengan kontrol $(\mathrm{P}<0,05)$. Konsentrasi kalsium 5,0-10,0 mg/L memberikan hasil yang baik dalam mempengaruhi pertumbuhan lobster. Hasil yang diperoleh dari penelitian ini membuktikan bahwa manajemen dalam konsentrasi kalsium yang seimbang pada media pemeliharaan lobster dapat diaplikasikan sehingga budidaya lobster dapat dilaksanakan secara intensif.
\end{abstract}

KATA KUNCI: kalsium, pertumbuhan, lobster, pemeliharaan

ABSTRACT: Assessment of calcium effect to development of intensive technology for freshwater lobster culture. By: Lies Emmawati Hadie, Wartono Hadie, and Irin Iriana Kusmini

Calcium mineral was need to support of lobster growth it's sufficient from feed and environment. Phase of harden carapace was need a high calcium. The calcium need did not fulfilled by hemolymphe body. And then the assessment of calcium effect was conducted to lobster culture. Complete randomized design was used for this research with different level of calcium hydroxide to the media namely $0.0 \mathrm{mg} / \mathrm{L}, 5.0 \mathrm{mg} / \mathrm{L}$, $10.0 \mathrm{mg} / \mathrm{L}$, and $15.0 \mathrm{mg} / \mathrm{L}$. The experiment was conducted in the completely randomized design with three replications. Result of this experiment showed that there were significant different positively compared than control $(P<0.05)$. Calcium level of 5.0-10.0 mg/L indicated positively affect to the growth of lobster. Result of this experiment to prove that management of calcium in the media rearing can be used to intensive culture of lobster.

KEYWORDS: calcium, growth, lobster, rearing 


\section{PENDAHULUAN}

Budidaya lobster air tawar red-claw (C. quadricarinatus) merupakan jenis komoditas yang prospektif untuk dikembangkan di kolam air tawar. Tipe kolam tanah dapat digunakan untuk usaha budidaya red-claw. Periode pemeliharaan dapat dikerjakan dalam waktu minimal empat bulan untuk mencapai ukuran konsumsi. Pertumbuhan red-claw relatif cepat dengan kisaran pertumbuhan harian mencapai rata-rata 2,23\%-3,52\%. Dampak introduksi lobster ini bersifat positif, karena terbukti spesies ini tidak merusak lingkungan. Sistem perbenihan lobster red-claw dapat dilakukan secara in-door dan out-door. Sistem in-door hanya memerlukan investasi yang relatif kecil, dan sistem out-door dapat diaplikasikan untuk wilayah yang memiliki kualitas air yang baik. Dampak dari hasil kaji terap ini mendapat respons yang relatif cepat dari Pemerintah Daerah Kabupaten Tabanan pada tahun 2006. Demikian pula pada tahun 2007 Pemerintah Provinsi Bali menetapkan Kabupaten Tabanan sebagai sentral pengembangan red-claw. Kontribusi yang diberikan oleh adanya pengembangan budidaya red-claw ini cukup signifikan dan memberikan dampak yang langsung dapat menyentuh kepentingan masyarakat luas (Hadie et al., 2008).

Dalam proses pertumbuhan lobster dibutuhkan mineral kalsium yang dapat dicukupi dari makanan dan lingkungan. Mineral merupakan faktor esensial dalam proses metabolisme dan pertumbuhan lobster. Menurut Mc Donald et al. (1988) mineral dibagi atas mineral esensial yang terdiri atas mayor elemen seperti $\mathrm{Ca}, \mathrm{P}, \mathrm{Mg}, \mathrm{Na}, \mathrm{S}$, dan $\mathrm{Cl}$ serta trace elemen seperti $\mathrm{Fe}, \mathrm{Mn}, \mathrm{Cu}, \mathrm{Co}, \mathrm{I}, \mathrm{Zn}, \mathrm{Si}$, $\mathrm{Mo}, \mathrm{Se}, \mathrm{Cr}, \mathrm{V}, \mathrm{Sn}, \mathrm{As}$, dan Ni. Di samping mineral esensial terdapat mineral yang tidak esensial antara lain $\mathrm{Ti}, \mathrm{Al}, \mathrm{B}$, dan $\mathrm{Pb}$. Konsentrasi mineral dalam tubuh lobster bergantung pada sumber pakan, lingkungan, spesies, laju pertumbuhan dan fisiologinya (Halver, 1989). Menurut Suriati (2000), kalsium dinyatakan sebagai nutrien mikro yang berfungsi untuk membentuk tulang, jaringan lunak, dan proses regulasi dalam tubuh dan berfungsi juga untuk menjaga keseimbangan asam basa dalam tubuh.

Kebutuhan kalsium akan meningkat dengan bertambahnya umur (Ton, 1992). Kalsium digunakan ikan trout untuk pembentukan jaringan struktural. Jumlah kalsium yang diserap dalam tubuh tergantung dari kadar kalsium dalam tubuh ikan. Apabila kalsium dalam pakan menurun, maka penyerapan kalsium dari lingkungan perairan akan meningkat. Menurut Lall (1989), pengambilan kalsium yang efektif pada ikan bersirip adalah melalui air. Namun kandungan kalsium dalam air rendah diperkirakan $\pm 0,34 \%$, sehingga mineral kalsium harus ada dalam pakan.

Kompiang (1989) menyatakan bahwa dalam kondisi netral dengan $\mathrm{pH}$ 5,0-7,0; umumnya mineral kalsium dalam pakan udang yang digunakan dalam bentuk senyawa seperti kalsium karbonat, trikalsium fosfat, dan dikalsium fosfat. Penentuan jumlah kalsium yang diberikan setiap hari merupakan hal yang kompleks, karena penyerapan kalsium dipengaruhi oleh berbagai faktor seperti umur, perbedaan jenis kelamin, dan proses fisiologis. Apabila terjadi kekurangan kalsium, maka pertumbuhan dapat terganggu bahkan dapat terhenti dan aktivitas jaringan akan terganggu. Jika kalsium dan fosfor tereduksi, maka pertumbuhan tulang akan terhenti pula.

Pertumbuhan lobster dapat berlangsung secara optimal jika kalsium yang masuk ke dalam tubuhnya memenuhi konsentrasi yang dibutuhkan. Peran kalsium dalam media air sangat dominan dalam proses pengerasan kulit lobster. Pada fase pengerasan kulit diperlukan kalsium yang cukup tinggi. Kebutuhan akan kalsium tidak dapat dipenuhi dari dalam tubuhnya yang tersimpan di dalam hemolimf. Karena kalsium yang berasal dari hemolimf hanya dapat memenuhi sebesar $10 \%$ dari kebutuhan dan sisanya diperoleh dari kalsium yang ada di dalam air. Jadi terdapat hubungan yang positif antara kadar kalsium hemolimf dengan kadar kalsium dalam air (Zaidy \& Hadie, 2009; Anonim, 2010).

Permasalahan yang terjadi pada lingkungan perairan tawar adalah $\mathrm{pH}$ dan konsentrasi alkalinitas yang rendah, sehingga hal ini dapat menghambat proses ganti kulit dan pertumbuhan udang. Pada $\mathrm{pH}$ di bawah 5,75; proses pengambilan kalsium terhambat, dan periode intermoulting menjadi lebih panjang (Adhikari et al., 2007). Demikian pula pada periode postmoulting pada lobster bergantung pada seberapa banyak kalsium yang diambil dari lingkungan yang digunakan untuk pengendapan dan pengerasan kulit yang baru (Adedboye, 1983). Kecepatan penyerapan kalsium dan kecepatan sekresi ion $\mathrm{H}^{+}$sangat terhambat oleh penurunan kadar kalsium pada 
lingkungan (Cameron, 1985b). Untuk mengatasi masalah pertumbuhan dan pengerasan kulit yang lambat tersebut, maka ketersediaan kalsium terlarut perlu ditingkatkan untuk menunjang proses pergantian kulit. Oleh karena itu, diperlukan kajian tentang keseimbangan mineral kalsium di dalam air, sehingga hal ini dapat mengintensifkan budidaya lobster.

Pengembangan usaha budidaya lobster belum mencapai level intensif karena terkendala dengan pertumbuhan lobster untuk mencapai ukuran pasar yaitu 5-6 inci. Peluang pasar yang tinggi di tingkat internasional tidak dapat dipenuhi oleh pembudidaya dalam ukuran konsumsi dan volume produksi. Sehingga diperlukan terobosan untuk menghasilkan lobster sesuai demand dengan teknologi budidaya secara intensif. Teknologi budidaya secara intensif dapat dilakukan dengan asumsi bahwa penambahan kalsium (Ca) pada media pemeliharaan akan mempercepat proses moulting. Sehingga percepatan moulting akan memacu pertumbuhan lobster secara optimal.

Tujuan riset adalah untuk mengkaji keseimbangan konsentrasi mineral kalsium dalam proses pertumbuhan lobster secara optimal. Sasaran yang dituju adalah intensifikasi budidaya lobster tawar secara progresif dalam skala nasional.

\section{BAHAN DAN METODOLOGI}

\section{Lokasi Kegiatan}

Penelitian dilakukan di Unit Pembenihan Rakyat di wilayah kota Bogor, Jawa Barat pada bulan September-November 2009.

Ikan uji yang digunakan adalah lobster air tawar jenis red-claw dengan bobot rata-rata $2,15 \pm 0,40 \mathrm{~g}$. Pakan yang diberikan ialah pelet dengan kadar protein $37,4 \%$. Sumber kalsium adalah $\mathrm{CaOH}_{2}$. Untuk analisis kualitas air digunakan reagen-kits. Alat bantu berupa termometer, filter air, timbangan, calipers, dan bahan bantu antara lain adalah shelter, polynet, seser, plastik terpal, dan pipa PVC.

Spesifikasi Calcium hydroxide/ $\mathrm{CaOH}_{2}$ yang digunakan adalah sebagai berikut:$$
\mathrm{M}=74.10 \mathrm{~g} / \mathrm{mol}
$$$$
\text { - Assay (acidimetric) }
$$$$
896 \%
$$$$
\text { - Carbonate }\left(\mathrm{CaCO}_{3}\right) \quad 7 \quad 3,0 \%
$$$$
\text { - Sulfur }\left(\mathrm{SO}_{4}\right)
$$$$
7 \quad 0,1 \%
$$
- Fe (iron)
$7 \quad 0,05 \%$
- $\mathrm{Na}$ (sodium)
$7 \quad 0,05 \%$
- Substances in soluble
- Chloride (Cl)
$7 \quad 0,03 \%$
- Heavy metal $(\mathrm{Pb})$
$7 \quad 0,005 \%$
- $\mathrm{Mg}$ (magnesium)
$7 \quad 0,003 \%$
- $\mathrm{Sr}$ (strontium)
$7 \quad 0,5 \%$
$7 \quad 0,05 \%$

Lobster air tawar dipelihara di dalam bak beton berukuran $2 \mathrm{~m} \times 3 \mathrm{~m}$. Bak pemeliharaan dilengkapi dengan sistem resirkulasi dan filter yang digunakan terbuat dari lembaran serat halus untuk menyaring sisa-sisa kotoran. Pemeliharaan lobster air tawar berlangsung selama 35 hari.

Rancangan penelitian dilakukan dengan menggunakan Rancangan Acak Lengkap dengan 4 perlakuan konsentrasi penambahan $\mathrm{Ca}(\mathrm{OH})_{2} /$ Calcium hydroxyde ke dalam media yaitu $0 \mathrm{mg} / \mathrm{L}, 5 \mathrm{mg} / \mathrm{L}, 10 \mathrm{mg} / \mathrm{L}$, dan $15 \mathrm{mg} / \mathrm{L}$. Masing-masing perlakuan mendapat 3 ulangan, sehingga jumlah satuan penelitian adalah 12 unit (Yitnosumarto, 1993; Sudjana, 1995).

Variabel yang dipantau adalah kualitas air yang meliputi suhu air $\left({ }^{\circ} \mathrm{C}\right), \mathrm{pH}$, carbonat hardness $\left({ }^{\circ} \mathrm{d}\right)$, total hardness $\left({ }^{\circ} \mathrm{d}\right), \mathrm{NH}_{3}(\mathrm{mg} / \mathrm{L}), \mathrm{NO}_{2}$ $(\mathrm{mg} / \mathrm{L}), \mathrm{NO}_{3}(\mathrm{mg} / \mathrm{L}), \mathrm{PO}_{4}(\mathrm{mg} / \mathrm{L}), \mathrm{Cu}(\mathrm{mg} / \mathrm{L}), \mathrm{Fe}$ $(\mathrm{mg} / \mathrm{L})$. Bobot dan panjang badan lobster $(\mathrm{g})$ diamati setiap satu minggu. Konsentrasi mineral Ca pada kulit lobster dan daging (\%) dianalisis dengan metode AAS (Atomic Absorption Spectrophotometer). Analisis dilaksanakan di Laboratorium Balai PenelitianTanah dan Balai Riset Perikanan Budidaya Air Tawar, Bogor.

\section{HASIL DAN BAHASAN}

Pengamatan terhadap pertumbuhan lobster selama 35 hari masa pemeliharaan lobster yang mendapat perlakuan kalsium dikemukakan pada Tabel 1.

Hasil yang diperoleh ini menunjukkan bahwa efek pemberian kalsium pada masa pemeliharaan lobster tawar berbeda secara signifikan di antara konsentrasi 5,0 mg/L dan $10,0 \mathrm{mg} / \mathrm{L}$ dengan konsentrasi $15,0 \mathrm{mg} / \mathrm{L}$ $(\mathrm{P}<0,05)$. Konsentrasi 5,0 mg/L memberikan hasil yang lebih baik dibandingkan dengan perlakuan lainnya serta kontrol. Pada perlakuan dengan konsentrasi $5,0 \mathrm{mg} / \mathrm{L}$ pertumbuhan panjang lobster mencapai $6,22 \mathrm{~cm}$ dengan rata-rata bobot 5,83 g. Demikian pula pola pertumbuhan bobot dari lobster kondisinya sama dengan pola pertumbuhan panjang. 
Tabel 1. Rata-rata pertumbuhan panjang (cm), bobot (g), dan sintasan (\%) lobster air tawar dengan perlakuan kalsium berbeda pada 35 hari masa pemeliharaan

Table 1. Average of total length $(\mathrm{cm})$, weight $(\mathrm{g})$, and survival rate $(\%)$ of red-claw with different calcium dosages for 35 days of rearing periode

\begin{tabular}{lccc}
\hline $\begin{array}{c}\text { Dosis kalsium } \\
\text { Calcium dosage }(\mathrm{mg} / \mathrm{L})\end{array}$ & $\begin{array}{c}\text { Panjang total } \\
\text { Total length }\end{array}$ (cm) & $\begin{array}{c}\text { Bobot } \\
\text { Weight }(\mathrm{g})\end{array}$ & $\begin{array}{c}\text { Sintasan } \\
\text { Survival rate (\%) }\end{array}$ \\
\hline 5 & 6.22 & $5.83^{\mathrm{a}}$ & $84.45^{\mathrm{a}}$ \\
10 & 5.96 & $5.34^{\mathrm{a}}$ & $86.67^{\mathrm{a}}$ \\
15 & 5.93 & $5.12^{\mathrm{b}}$ & $55.55^{\mathrm{b}}$ \\
Kontrol (Control) & 5.92 & $5.06^{\mathrm{b}}$ & $86.67^{\mathrm{a}}$ \\
\hline
\end{tabular}

Keterangan (Remark):

Angka-angka dalam kolom dan baris yang sama diikuti oleh superscript yang sama menunjukkan tidak berbeda nyata $(\mathrm{P}>0,05)$

Number in the same column and row followed by the same superscript are not significant different $(P>0.05)$

Dalam proses pertumbuhan lobster dibutuhkan mineral kalsium yang dapat dicukupi dari makanan dan lingkungan. Pertumbuhan lobster dapat berlangsung secara optimal jika kalsium yang masuk ke dalam tubuhnya memenuhi konsentrasi yang dibutuhkan. Peran kalsium dalam media air sangat dominan dalam proses pengerasan kulit lobster.

Pada fase pengerasan kulit diperlukan kalsium yang cukup tinggi. Kebutuhan akan kalsium tidak dapat dipenuhi dari dalam tubuhnya yang tersimpan di dalam hemolimf. Karena kalsium yang berasal dari hemolimf hanya dapat memenuhi sebesar 10\% dari kebutuhan dan sisanya diperoleh dari kalsium yang ada di dalam air. Jadi terdapat hubungan yang positif antara kadar kalsium hemolimf dengan kadar kalsium dalam air. Rataan kadar kalsium dalam daging dan kulit lobster air tawar setelah masa pemeliharaan selama 35 hari dikemukakan dalam Tabel 2.

Pengaruh yang nyata akan pengaruh konsentrasi kalsium terhadap pertumbuhan lobster. Pada dosis yang rendah yaitu 5,0-10,0 $\mathrm{mg} / \mathrm{L}$ ternyata penambahan kalsium dalam media pemeliharaan memberikan pengaruh yang lebih baik dibandingkan dosis yang tinggi maupun kontrol. Hasil yang diperoleh ini sejalan dengan pernyataan Dag et al. (1991) bahwa terdapat hubungan yang positif antara kadar kalsium kulit dan kadar kalsium lingkungan yang terjadi sejalan dengan
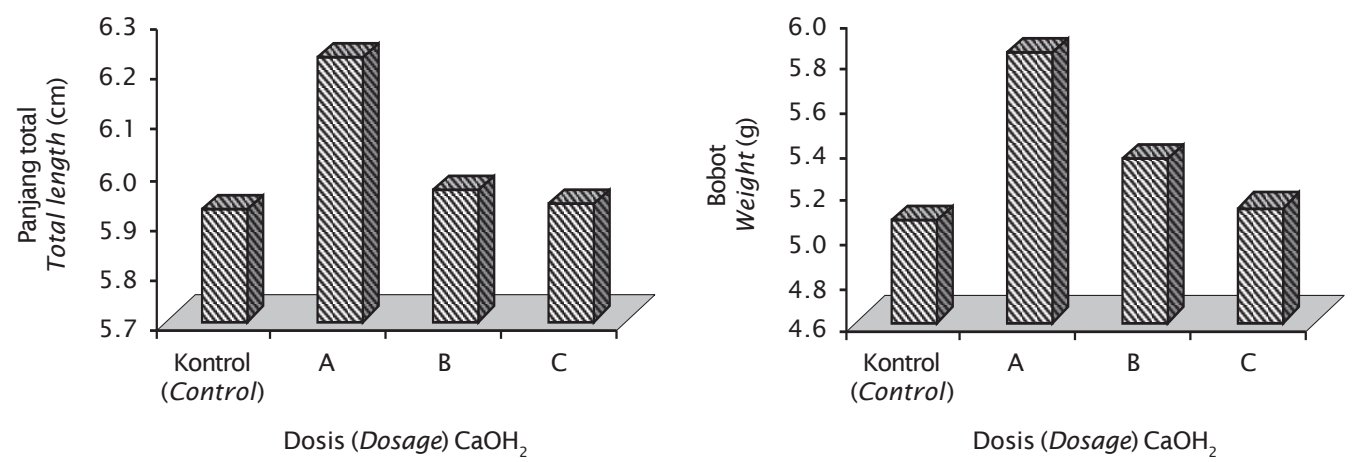

Gambar 1. Pertumbuhan panjang total $(\mathrm{cm})$ serta bobot $(\mathrm{g})$ lobster air tawar dengan perlakuan kalsium berbeda

Figure 1. Growth of total length $(\mathrm{cm})$ and weight $(\mathrm{g})$ of red-claw with different calcium dosage 
Tabel 2. Rataan kadar kalsium (\%) pada daging dan kulit lobster air tawar dengan pemberian kalsium berbeda

Table 2. Mean of calcium (\%) concentration of meat and exoskeleton of red-claw with different dosage

\begin{tabular}{lcc}
\hline $\begin{array}{c}\text { Dosis kalsium hidroksida } \\
\text { Calcium hydroxide } \\
\text { dosage }(\mathrm{mg} / \mathrm{L})\end{array}$ & $\begin{array}{c}\text { Kadar kalsium pada daging" } \\
\text { Concentration calcium } \\
\text { in meat (\%) }\end{array}$ & $\begin{array}{c}\text { Kadar kalsium pada kulit" } \\
\text { Concentration calcium } \\
\text { in exoskelet on (\%) }\end{array}$ \\
\hline 5 & 0.31 & 11.57 \\
10 & 0.23 & 11.26 \\
15 & 0.16 & 10.25 \\
Kontrol (Control) & 0.11 & 10.07 \\
\hline
\end{tabular}

Sampel kering $105^{\circ} \mathrm{C}$, Laboratorium Balai Penelitian Tanah, Bogor

Dry sample $105^{\circ} \mathrm{C}$, Laboratory of Land Research Institute, Bogor

pertukaran kalsium secara terus-menerus antara tubuh dan lingkungan.

Kalsium secara aktif dipindahkan oleh selsel usus, dan besarnya aktivitas perpindahan kalsium dipengaruhi oleh beberapa faktor antara lain bagian dari usus, zat-zat nutrisi serta status hormon. Kalsium juga dapat diabsorpsi melalui mekanisme ketidakjenuhan (non saturable mechanism) yang tergantung pada vitamin $\mathrm{D}$ dan ditandai oleh suatu transfer yang bersifat difusi. Absorpsi secara aktif diatur oleh suatu sistem yang disebut gate keeper mechanism yang mengatur intake dan output dari kalsium dari makanan ke dalam dan diekskresi oleh tubuh. Kecepatan ekskresi meningkat seiring dengan menurunnya masukan kalsium dari makanan, dan juga dengan meningkatnya kebutuhan akan mineral tersebut selama periode pertumbuhan (Piliang, 2000).

Penelitian Davis et al. (1992; 2005) bahwa dalam ransum pakan udang perlu mengandung mineral, karena mineral tersebut memiliki peran yang penting dalam pertumbuhan udang. Demikian pula menurut Kompiang (1989) bahwa dalam kondisi netral yaitu $\mathrm{pH}$ 5,0-7,0; umumnya mineral kalsium dalam pakan udang yang digunakan dalam bentuk senyawa seperti kalsium karbonat, trikalsium, dan dikalsium fosfat.

Penelitian mengenai fungsi mineral yang esensial dalam ransum pakan udang Penaeus vannamei menunjukkan pentingnya mineral seperti Mg, Mn, Fe, Zn, dan Cu. Ransum pakan udang vaname yang tidak menggunakan mineral-mineral tersebut, ternyata mengalami penurunan proses mineralisasi. Hal ini terbukti berdasarkan hasil analisis mineral pada hepatopancreas dan carapace udang vaname (Davis et al., 1992).

Udang vaname juga membutuhkan fosfor untuk pertumbuhannya, dan kadar fosfor yang sesuai untuk udang tersebut adalah dalam bentuk kalsium fosfat monobasik pada level 1,33-1,7\% (Pan et al., 2006).

Sehubungan dengan parameter kualitas air selama penelitian berlangsung dikemukakan pada Tabel 3.

Kisaran nilai konsentrasi kalsium memperlihatkan adanya variasi yang cukup tinggi pada perlakuan $\mathrm{CaOH}_{2}$ dengan kadar $10 \mathrm{mg} / \mathrm{L}$ dibandingkan dengan perlakuan $5 \mathrm{mg} / \mathrm{L}, 15$ $\mathrm{mg} / \mathrm{L}$, dan kontrol. Namun tingginya variasi kalsium tidak mempengaruhi secara signifikan terhadap derajat sintasan lobster (Tabel 1). Faktor yang tampaknya memberikan pengaruh langsung pada sintasan adalah tingkat konsentrasi $\mathrm{CaOH}_{2}$ yang diaplikasikan pada media air. Pada perlakuan $15 \mathrm{mg} / \mathrm{L} \mathrm{CaOH}_{2}$ menunjukkan derajat sintasan yang relatif lebih rendah dibandingkan dengan perlakuan lainnya dan kontrol. Derajat sintasan pada konsentrasi $15 \mathrm{mg} / \mathrm{L}$ hanya mencapai 55,55\%, dan pada perlakuan $5 \mathrm{mg} / \mathrm{L}, 10 \mathrm{mg} / \mathrm{L}$ serta kontrol mencapai 84,45\%-86,67\%.

Tingkat sintasan yang relatif rendah pada perlakuan dengan kadar $\mathrm{CaOH}_{2}$ sebesar 15,0 $\mathrm{mg} / \mathrm{L}$ memperlihatkan bahwa konsentrasi yang tinggi ternyata memberikan efek negatif. Dengan demikian mineral kalsium yang perlu ditambahkan untuk mempercepat pertum- 
Tabel 3. Kisaran nilai kesadahan karbonat $/ \mathrm{kH}\left({ }^{\circ} \mathrm{d}\right)$, kesadahan total $/ \mathrm{gH}\left({ }^{\circ} \mathrm{d}\right), \mathrm{NH}_{3}(\mathrm{mg} / \mathrm{L}), \mathrm{NO}_{2}$ $(\mathrm{mg} / \mathrm{L}), \mathrm{NO}_{3}(\mathrm{mg} / \mathrm{L}), \mathrm{PO}_{4}(\mathrm{mg} / \mathrm{L}), \mathrm{pH}, \mathrm{Cu}(\mathrm{mg} / \mathrm{L})$, dan $\mathrm{Fe}(\mathrm{mg} / \mathrm{L})$ pada media pemeliharaan lobster tawar dengan konsentrasi kalsium berbeda

Table 3. Range of carbonate hardness $/ \mathrm{kH}\left({ }^{\circ} \mathrm{d}\right)$, total hardness $/ \mathrm{gH}\left({ }^{\circ} \mathrm{d}\right), \mathrm{NH}_{3}(\mathrm{mg} / \mathrm{L}), \mathrm{NO}_{2}$ $(\mathrm{mg} / \mathrm{L}), \mathrm{NO}_{3}(\mathrm{mg} / \mathrm{L}), \mathrm{PO}_{4}(\mathrm{mg} / \mathrm{L}), \mathrm{pH}, \mathrm{Cu}(\mathrm{mg} / \mathrm{L})$, and $\mathrm{Fe}(\mathrm{mg} / \mathrm{L})$ on medium of redclaw with different calcium dosage

\begin{tabular}{|c|c|c|c|c|}
\hline \multirow{2}{*}{$\begin{array}{l}\text { Parameter } \\
\text { Variables }\end{array}$} & \multicolumn{3}{|c|}{ Kalsium hidroksida (Calcium hydroxide) } & \multirow{2}{*}{$\begin{array}{l}\text { Kont rol } \\
\text { Control }\end{array}$} \\
\hline & $0.5 \mathrm{mg} / \mathrm{L}$ & $10.0 \mathrm{mg} / \mathrm{L}$ & $15.0 \mathrm{mg} / \mathrm{L}$ & \\
\hline Ke sadahan karbonat/kH $\left({ }^{\circ} \mathrm{d}\right)$ & $3.0-5.0$ & $3.0-7.0$ & $3.0-5.0$ & $3.0-5.0$ \\
\hline \multicolumn{5}{|l|}{ Carbonate hardness $/ \mathrm{kH}\left({ }^{\circ} \mathrm{d}\right)$} \\
\hline Ke sadahan total $/ \mathrm{gH}\left({ }^{\circ} \mathrm{d}\right)$ & 5 & 5 & 5 & 5 \\
\hline \multicolumn{5}{|l|}{ Total hardness $/ g H\left({ }^{\circ} d\right)$} \\
\hline Amoniak/ $\mathrm{NH}_{3}(\mathrm{mg} / \mathrm{L})$ & $0.08-0.1$ & $0.03-0.1$ & $0.08-0.1$ & $0.003-0.1$ \\
\hline \multicolumn{5}{|l|}{ Ammonia/NH ${ }_{3}(\mathrm{mg} / \mathrm{L})$} \\
\hline Nitrit/ $\mathrm{NO}_{2}(\mathrm{mg} / \mathrm{L})$ & $0.01-0.5$ & $0.01-0.5$ & $0.01-0.05$ & $0.01-0.05$ \\
\hline \multicolumn{5}{|l|}{ Nitrite $/ \mathrm{NO}_{2}(\mathrm{mg} / \mathrm{L})$} \\
\hline Nitrat/ $\mathrm{NO}_{3}(\mathrm{mg} / \mathrm{L})$ & 0 & 0 & 0 & 0 \\
\hline \multicolumn{5}{|l|}{ Nitrate $/ \mathrm{NO}_{3}(\mathrm{mg} / \mathrm{L})$} \\
\hline Fosfat/PO $4(\mathrm{mg} / \mathrm{L})$ & 0.25 & 0.25 & 0.25 & 0.25 \\
\hline \multicolumn{5}{|l|}{ Phosphate $/ \mathrm{PO}_{4}(\mathrm{mg} / \mathrm{L})$} \\
\hline $\mathrm{pH}$ & $7.5-8.5$ & $7.5-8.0$ & $7.5-8.5$ & $7.0-8.0$ \\
\hline \multicolumn{5}{|l|}{$p H$} \\
\hline Kuprum/Cu (mg/L) & 0.1 & 0.1 & 0.1 & 0.1 \\
\hline \multicolumn{5}{|l|}{ Cuprum $/ \mathrm{Cu}(\mathrm{mg} / \mathrm{L})$} \\
\hline $\mathrm{Besi} / \mathrm{Fe}(\mathrm{mg} / \mathrm{L})$ & 0.25 & 0.25 & 0.25 & 0.25 \\
\hline Iron/Fe ( $\mathrm{mg} / \mathrm{L})$ & & & & \\
\hline
\end{tabular}

Tabel 4. Kecepatan pertumbuhan harian (\%/hari) pada pertumbuhan bobot lobster air tawar dengan perlakuan konsentrasi kalsium berbeda

Table 4. Average daily growth rate (\%/day) of weight of red-claw with different calcium dosage

\begin{tabular}{lc}
\hline $\begin{array}{c}\text { Kadar kalsium hidroksida } \\
\text { Dosage of calcium hydroxide }(\mathbf{m g} / \mathrm{L})\end{array}$ & $\begin{array}{c}\text { Kecepatan pert umbuhan bobot }(\% / \text { hari) } \\
\text { Daily growth rate of growt } \mathbf{~}(\% / \text { day })\end{array}$ \\
\hline 5.0 & 3.80 \\
10.0 & 3.42 \\
15.0 & 3.28 \\
Kontrol (Control) & 3.16 \\
\hline
\end{tabular}

buhan lobster sebaiknya tidak melebihi kebutuhan yang optimal.

Efek pemberian calcium hydroxide terlihat mempengaruhi kecepatan pertumbuhan harian pada pertumbuhan panjang dan bobot lobster. Data kecepatan pertumbuhan panjang dan bobot harian disajikan pada Tabel 4 .

Kecepatan pertumbuhan harian pada setiap perlakuan menunjukkan perbedaan yang signifikan. Dengan demikian dapat dilihat 
bahwa kecepatan pertumbuhan bobot lebih cepat dibandingkan dengan pertumbuhan panjang harian. Data ini menunjukkan bahwa pertumbuhan lobster bersifat allometric. Hal ini mengartikan bahwa pertumbuhan panjang tidak selalu disertai dengan pertumbuhan bobot lobster.

Kecepatan pertumbuhan bobot lobster yang terbaik pada perlakuan konsentrasi $5,0 \%$ mencapai 3,80\%/hari. Kemudian urutan berikutnya adalah perlakuan $10,0 \%$ yang mencapai 3,42\%/hari dan 3,28\%/hari pada dosis $15,0 \%$. Jika dibandingkan dengan kontrol semua perlakuan menunjukkan hasil yang lebih tinggi.

\section{KESIMPULAN}

Efek pemberian kalsium $\left(\mathrm{CaOH}_{2}\right)$ pada lobster air tawar terlihat secara signifikan memberikan efek yang positif dan jauh lebih baik dibandingkan dengan kontrol. Hasil yang diperoleh dari penelitian ini membuktikan bahwa manajemen dalam konsentrasi mineral kalsium yg seimbang pada media pemeliharaan lobster dapat diaplikasikan. Sehingga budidaya lobster dapat dilaksanakan secara intensif. Hal ini merupakan bentuk kontribusi yang positif dari penelitian untuk mendorong pengembangan teknik budidaya lobster dari ekstensif menjadi secara intensif. Manfaat hasil kajian tersebut dapat dijadikan dasar dalam pengembangan manajemen budidaya lobster secara intensif.

\section{DAFTAR ACUAN}

Adhikari, S., Chaurasia, V.S., Naqvi, A.A., \& Pillai, B.R. 2007. Survival and growth of Macrobrcahium rosenbergii (de Man) juvenile in relation to calcium hardness and bicarbonate alkalinity. Turkish J. of Fisheries and Aquatic Sciences, 7: 23-26.

Adedboye, D. 1983. Table size and physiological condition of the crayfish in relation to calcium ion accumulation. Dalam Goldman, C.R. (Ed.). Avi Publishing Co. Inc, Connecticut. Freshwater Crayfish, 5: 115-125.

Anonim. 2010. The Lobster's Life Cycle. http:/ /www.parl.ns.ca/lobster/life cycle.htm. diakses tanggal 30 April 2010.

Baron, D.N. 1990. Kapita selekta "Patologi Klinik" (A short text book of chemical pathology) oleh D.N. Baron; alih bahasa, Petrus Andrianto, Johannes Gunawan. Ed. 4. Jakarta: EGC, 201 pp.
Cameron, J.N. 1985b. Post-moult calcification in the blue crab (Callinectus sapidus): Relation ships between apparent net $\mathrm{H}^{+}$excretion, calcium and bicarbonate. J. Exp. Biol., 119: 275-285.

Dag, H., Grill, K., \& Ingunn, L. 1991. Calcium uptake from food and water in the crayfish Astacus astacus (L.1758), Measured By Radioactive $45 \mathrm{Ca}$ (Decapoda, Astacideae). Crustaceana, 60(91): 76-83.

Davis, D.A., Lawrence, A.L., Gatlin, D.M. III. 1992. Requirement of Penaeus vannamei: A Preliminary Examination of the Dietary Essentiality for Thirteen Minerals. J. of the World. Aquaculture Society, 23(1): 8-14.

Davis, D.A., Boyd, C.E., \& Saoud, I.P. 2005. Effect of potassium and age of growth and survival of Litopenaeus vannamei post larvae reared in inland low salinity well waters in alabama. J. of the World Aquaculture Society, 36(3): 416-419.

Hadie, L.E., Hadie, W., Hikmayani, Y., \& Listyanto, N. 2008. Kebijakan dalam pengembangan budidaya lobster C. quadricarinatus. Analisis Kebijakan Pembangunan Perikanan Budidaya. Pusat Riset Perikanan Budidaya. Badan Riset Kelautan dan Perikanan. Departemen Kelautan dan Perikanan, hlm. 35-45.

Halver, J.E. 1989. Fish Nutrition. Academic Press, N.Y. Boston, 712 pp.

Kompiang, I.P. 1989. Prinsip dasar nutrisi. Short Course Budidaya Udang Intensif. Jakarta, $12 \mathrm{hlm}$.

Lall, S.W. 1989. The minerals. Dalam J.E. Halver (ed.). Fish Nutrition Academic Press. San Diego, New York, p. 219-257.

Mc Donald, P., Edwards, R.A., \& Green Halgh, J.F.D. 1988. Animal nutrition. Fourth Edition. Longman. New York, 543 pp.

Pan, Q., Chen, X.Y., F.Li., Bi, Y.Z., \& Zheng, S.X. 2006. Response of juvenile Litopenaeus vannamei to varying levels of calcium phosphate monobasic supplemented to a practical diet. J. of the World Aquaculture Society, 258: 388-395.

Piliang, W.G. 2000. Nutrisi mineral. Institut Pertanian Bogor. Edisi ke-3, hlm.13-38.

Suriati, R.H.S. 2000. Pengaruh konsentrasi kalsium media terhadap kelangsungan hidup ikan jambal. Program Studi Budidaya Perairan. Faperik. IPB. Bogor, $4 \mathrm{hlm}$.

Sudjana. 1992. Teknik analisis regresi dan korelasi bagi para peneliti. Penerbit 
TARSITO. Bandung, hlm. 183-188.

Sudjana. 1995. Desain dan analisis eksperimen. Edisi IV. Penerbit TARSITO. Bandung, hlm. 292-303.

Ton, F. 1992. Biokimia, nutrisi, dan metabolisme. UI Press. Jakarta, $258 \mathrm{hlm}$.

Yitnosumarto, S. 1993. Percobaan perancangan, analisis, dan interpretasinya. Gramedia Pustaka Utama. Jakarta, 225 hlm.
Zaidy, A.B. \& Hadie, W. 2009. Pengaruh penambahan kalsium pada media terhadap siklus moulting dan pertumbuhan biomassa udang galah, Macrobrachium rosenbergii (de Man). J. Ris. Akuakultur, 4(2): 179-189. 